\title{
Do Sustainability Reports Show Corporate Social Responsibility (CSR) and Corporate Social Irresponsibility (CSI)?
}

\author{
Paulina Permatasari ${ }^{1}$, Pius S. Kartasasmita ${ }^{2}$, Tulus Suryanto ${ }^{3}$ \\ \{paulina@unpar.ac.id ${ }^{1}$, pius@unpar.ac.id², tulus@radenintan.ac.id ${ }^{3}$ ) \\ Accounting Department, Parahyangan Catholic University, Indonesia ${ }^{1}$, Department of Public \\ Administration and Graduate Program in Social Sciences, Parahyangan Catholic University ${ }^{2}$, Indonesia, \\ Postgraduate Program UIN Raden Intan Lampung ${ }^{3}$
}

\begin{abstract}
The awareness of sustainability in Indonesia is increasing from year to year. This is evidenced by the increasing number of sustainability reports that companies report. But some case study evidences from around the world have shown how companies can communicate their corporate social responsibility (CSR) policies while also getting involved in corporate social irresponsibility (CSI). Besides, this has not been accompanied by regulations that enforce the increase of reliability in sustainability reporting. In addition, the absence of a standard sustainability report that could be applied in all industries may also result in fraud (incomplete information disclosure) in sustainability reporting. This study shows that companies still emphasizes to have good company image even when disclosed negative information that occurs in the company. Sustainability reporting, which should have been a transparent communication tool, now seems to be polished into a tool to build good corporate reputation
\end{abstract}

Keywords: Sustainability Reporting, Sustainability Fraud, Corporate Social Responsibility, Corporate Social Irresponsibility 


\section{Introduction}

Corporate social responsibility (CSR) is one of the crucial topics in modern businesses that encompasses companies, consumers, and other stakeholders. CSR is defined as "an organization's status and activities with respect to its perceived societal obligations" [1]. On one hand, companies are exerting greater efforts for their CSR initiatives, as well as the communities and consumers are increasingly paying more attention to the companies' CSR actions [2], [3]. While on the other hand, corporate social irresponsibility (CSI) has been given less attention. Even so, in recent years, a number of studies on this subject have been conducted [4], [5], [6]. Companies publish CSR reports to give information to their stakeholders about the companies' CSR efforts. However, several literatures indicate that these reports can be used as a way to offset the companies' involvement in CSI [7].

In recent years, some case study evidences from around the world have shown how companies can communicate their CSR policies while also getting involved in CSI [7]. Previous studies on the relationship between the implementation of CSR policies and involvement in CSI also show that companies can be involved and communicate their CSR activities to offset their irresponsible behavior in the past [8][9]. However, the number of studies on this topic is still low [10], and very little attention has been given to analyze how the involvement of companies in CSI is related to their CSR communications, especially regarding the CSR reports. CSR report is the main tool that companies have to communicate their social and environmental activities to the stakeholders [11] [12] [13][14]. Sometimes this report is criticized because it allows companies to only show the good side of their activities [15] in an attempt to gain and maintain their external legitimacies [16] [17] [18].

Besides, according to some studies, CSR reports may be deliberately used by a company in response to its involvement in CSI "to apologize, explain, justify, or blame others for its actions, thereby helping to maintain legitimacy" [16]. In this paper, we describe the practice of CSIR happened along with the "good sustainability reporting" describing how companies" practice in sustainability reporting showed react to their irresponsible business conduct. 


\section{Literature Review}

\subsection{Corporate Social Responsibility}

The history of corporate social responsibility has been of global concern for more than 50 years, although until now there is no generally accepted definition of corporate social responsibility [19]. There are various perspectives that have been used to explain CSR including institutional theory, agency theory, legitimacy theory, stakeholder theory, resource dependency theory, and resource-based views [20]. Dahlsrud [21] conducted an analysis based on 37 definitions of CSR that cover five aspects. The five aspects are: economic aspects, social aspects, environmental aspects, stakeholder aspects, and voluntary aspects. However, with many definitions of CSR, people usually define CSR as a company's commitment to maximizing its long-term beneficial impact and minimizing or eliminating harmful effects by considering economic, social and environmental aspects. [22]. In general, companies usually implement CSR practices by holding charity activities [23] while only a few companies are motivated to incorporate CSR into their business strategies [24].

The mandated law issued by the government that requires companies to carry out CSR as part of the company's activities has encouraged companies to start caring about CSR issues [25]. On the other hand, several countries also provide options for companies to carry out CSR activities. The company also has complete freedom in regulating how much budget to spend on CSR activities and what CSR activities to do. However, even though CSR is not yet mandatory, the community and other stakeholders still hope that the company will continue to care about environmental, economic and social issues in the countries where they operate [26].

\subsection{Sustainability}

Around the world in recent times, issues regarding sustainability have become increasingly prominent among companies and their stakeholders [27]. The definition of sustainability itself is a study related to natural work systems, diverse and produces everything needed for ecology toemain balanced [28]. Pursuing sustainability is defined as an agreed process while maintaining conditions in which humans and nature can live in harmony and productively to support present and future generations [29]. Sustainability can also be interpreted as fulfilling one's own needs by thinking about its impact on future generations. Sustainability does not only talk about the environment, but also talks about economic and social issues [30]. The sustainability of organizational innovation can be considered as a change in work norms and systems within the company by considering sustainability issues [31]. This can be achieved if everyone concern about three main issues : economic, environmental, and social. If the company wants to communicated its sustainability performance, the company needs a powerful tool. The tool that used for reporting this performance is Sustainability Report, which will be explained in the next section.

\subsection{Sustainability Report}

Over the last few years, the trend in the number of companies publishing sustainability reports has grown rapidly. Companies are starting to change the way they do business and are starting to report on their sustainability performance [32]. However, despite the large number of sustainability reports published in the public, questions arise about what information should be included in a sustainability report and how to include this information in a sustainability report [33]. As defined by the Global Reporting Initiative (GRI), 'sustainability reporting or disclosure is the practice of measuring, reporting, and being accountable to internal and external stakeholders for organizational performance towards the goal of sustainable 
development' [34]. In most countries of the world, corporate sustainability reporting remains voluntary. Several organizations have issued standards used in preparing sustainability reports. One of the most widely used standards in sustainability reporting is the GRI standard issued by the Global Reporting Initiative (GRI) [35].

Based on Diouf and Boiral [36]. There are six sustainability report principle that GRI issued that cover main aspect of sustainability. The principles are: balance, comparability, accuracy, timeliness, clarity, and reliability. The principle of balance can be interpreted that the sustainability report published by the company reflects all information, both positive and negative information that occurs within the company. This principle makes the sustainability report an assessment of the company's overall performance from economic, environmental and social aspects.

\subsection{Fraud}

Fraud is a general term that includes all the ingenious means by which a person obtains profit in the wrong way. There is no specific definition of fraud, because every person had different way to commit act of fraud [37]. The person who commit fraud that applicable in Delaware are "Any person who knowingly, and with intent to injure, defraud or deceive any insurer, files a statement of claim containing any false, incomplete or misleading information is guilty of a felony." 


\subsection{Sustainability Fraud \\ 2.5.1. Concept and Definition}

Based on the fraud concept described at the section above, we can conclude that stated an incomplete or misleading information can be categorized as fraud. "Sustainability fraud" can be defined as fraud perpetrated by some people in the sustainability department [38]. The Fraud Triangle is a framework used to explain the motivation behind a decision to commit fraud and/or to make a structured assessment of the fraud risk [39]. In general, the fraud triangle requires (1) pressure to force someone to commit fraud; (2) opportunities; and (3) rationalization of a person to commit fraud. The company's pressures to act fraudulently will appear when the impact of business activities is expected to negatively affect the company's reputation. One of the opportunities to commit fraud in sustainability is the lack of standard and assurance of Sustainability Report. One of the rationalization in doing sustainability fraud is the thought that the company's activities that cause negative effects to the society won't be noticed as long as the company doesn't disclosed it [40]. As sustainability becomes a mainstream issue and is further integrated into annual reports, this leads to an increase in incentives, opportunities and rationalisation for companies and individuals to step into fraudulent behaviour in order to exploit sustainability efforts for their own advantage [39].

\subsubsection{Previous Studies on Sustainability Fraud}

After conducted previous study on sustainability fraud, we found that the companies doing the sustainability fraud by disclosing incomplete negative activities in their sustainability reporting. Companies tend to report information in their sustainability reports if the company feels that there is a benefit from disclosing the information. If the company feels that it has not received any benefits and may even get a loss, the company tends not to disclose the information [41]. We also found some reasons why companies doing sustainability fraud. The reasons are: a) Lack of mandatory law for publishing sustainability reporting; b) Lack of sustainability reporting standard [42]; c) Weak regulations for unethical activities [43]; d) Management incompetence [44][45]; e) Lack of independence assurance from external parties [4]; f) Lack of awareness for sustainability fraud; g) Lack of fraud detection and prevention [38]; and h) The voluntary nature and optional auditing requirements [46]. 


\section{Methods}

This research was conducted to assess the possibility of fraud or undisclosed information on sustainability reports in Indonesia. We are looking for information related to negative cases / news about 133 companies in Indonesia. Furthermore, we look at the company's sustainability report and analyse the disclosures related to the existing cases. Of the 133 companies that received negative news, only 23 published sustainability reports.

Conducting research is one of the various methods used to find a solution for a particular problem, under a comprehensive framework with the inclusion of existing situational factors. In carrying out research, certain methods are needed to ensure that the research process is able to run systematically and in an organized manner. The selection of appropriate research methods helps in identifying a problem, collecting and analysing data, as well as elaborating a valid conclusion from all the collected data [25].

The method used in this study is a combination of descriptive method and content analysis. Descriptive method has proven its usefulness in providing an overview of relevant aspects from various perspectives, such as an individual, an organisation or industry orientation. While content analysis is a technique to collect and analyse specific contents [26]. The word 'content' itself can refer to various elements, such as words, symbols, meanings, ideas, images, themes, or messages that are communicated. In other word, content analysis is a data collection technique which consequently converts qualitative data to a quantitative format through the process of codification [27]. Therefore, both methods used in this study is considered sufficient to analyse the fraud in Indonesian companies' sustainability report.

\section{Result and Discussion}

In this section, we will discuss and analyse the disclosure of negative information / cases in company's economy, environment, and social sustainability indicator. In this study we examined 133 companies in Indonesia. From these 133 companies, only 23 or $17.29 \%$ of the companies that published sustainability report. We will explain each indicator in more detail in the sections below.

\subsection{Cases Related to the Economic Aspect}

Cases about economic aspect that we found were related to 4 indicators. For the explanation, we described in the points below:

a. Direct economic value generated and distributed (GRI 201-1), the negative cases or issues found are mostly related to financial reports and tax evasion. Most of the issues that occur in financial statements are related to claims for payment of debts or compensation to companies, late / inappropriate financial reports, and corporate tax evasion. Most companies that have negative case or issue do not publish a sustainability report and there are no companies that disclose negative cases or issues that are reported in their sustainability reports.

b. Defined benefit plan obligations and other retirement plans (GRI 201-3), the cases or negative issues found were related to demonstrations conducted by employees with unilateral layoffs and severance pay that was not given when the employee was laid off. Most companies that have negative case or issue do not publish a sustainability report 
and most companies that publish sustainability reports do not disclose the number of employees who were laid off, the conflicts that occurred, and the next steps to be taken.

c. Confirmed incidents of corruption and actions taken (GRI 205-3), negative cases or issues found were related to incidents of employees who were caught committing corruption / bribery. Most companies that publish sustainability reports have disclosed the number of corruption / bribery incidents that occurred during a certain year. The company also disclosed the system implemented to prevent corruption or bribery, one of which is by implementing a whistle blowing system.

d. Legal actions for anti-competitive behavior, anti-trust, and monopoly practices (GRI 206-1), negative cases or issues found related to the incidence of fines/sanctions imposed by the Business Competition Supervisory Commission in Indonesia. All companies that have cases on this indicator do not make sustainability reports.

\subsection{Cases Related to the Environmental Aspect}

In this section, we will explain cases about environmental aspect. Cases that we found were related to in 7 indicators. The following are our explanation which is divided into 5 points, i.e.:

a. Management of water discharge-related impacts (GRI 303-2), negative cases or negative issues found related to the incident of an oil spill in the river by a company in Indonesia. The company has disclosed information related to the case in their sustainability report.

b. Operational sites owned, leased, managed in, or adjacent to, protected areas and areas of high biodiversity value outside protected areas (GRI 304-1) and Significant impacts of activities, products, and services on biodiversity (GRI 304-2), negative cases or negative issues found related to the damage of biodiversity due to the company's operational activities or the construction of company facilities. Some companies do not publish sustainability reports. Some companies disclosed information related to efforts made to protect biodiversity, but did not disclose cases related to biodiversity damage in detail in their sustainability reports.

c. Direct (Scope 1) GHG emissions (GRI 305-1) and Energy indirect (Scope 2) GHG emissions (GRI 305-2), negative cases or negative issues found related to the pipe leak incident resulting in air pollution and other activities that cause air pollution. The company does not disclose this case in their sustainability report.

d. Waste by type and disposal method (GRI 306-2), negative cases or negative issues found related to the waste resulting from the company's operations which results in pollution and disease in local residents or deliberately disposing of waste. Some companies do not publish sustainability reports. Companies that publish sustainability reports make disclosures about the waste management business carried out by the company but most of them do not report any negative impacts from the waste produced.

e. Non-compliance with environmental laws and regulations (GRI 307-1), negative cases or negative issues found related to the construction of company facilities in a way that damages biodiversity and results in pollution, fire, or other environmental damage, operational activities that cause environmental pollution, improper disposal of company waste. Most of the companies do not have a sustainability report. Most companies that produce sustainability reports only explain briefly, and some do not even disclose cases of non-compliance that have occurred. 


\subsection{Cases Related to the Social Aspect}

The last section, we talk about cases related to the social aspect. There are 7 indicators related to the cases, i.e.:

a. Occupational health and safety management system (GRI 403-1), Prevention and mitigation of occupational health and safety impacts directly linked by business relationships (GRI 403-7), Workers covered by an occupational health and safety management system (GRI 403-8), and Work-related injuries (GRI 403-9) negative cases or negative issues found related to the accidents and deaths in the work environment. Most of the companies studied had work accident cases, but most companies did not have a sustainability report. Companies that have a sustainability report have disclosed the number of incidents (minor, moderate, severe) that occurred within the company and the efforts made by the company regarding the issue of occupational health and safety.

b. Operations and suppliers at significant risk for incidents of child labour (GRI 408-1), negative cases or negative issues found related to the existence of child labor in the company. All companies that have these cases do not have sustainability reports.

c. Incidents of violations involving rights of indigenous peoples (GRI 411-1), negative cases or negative issues found related to the violation of human rights in the company. All companies that have these cases do not have sustainability reports.

d. Incidents of non-compliance concerning the health and safety impacts of products and services (GRI 416-2), negative cases or negative issues found related to the losses experienced by consumers due to unsafe products. The company does not have a sustainability report.

\section{Conclusion}

The number of publication of sustainability reports in Indonesia continues to increase. However, this was not accompanied by the issuance of mandatory sustainability reports and sustainability report standard in all sectors. This resulted in fraud (incomplete disclosure of information) in the sustainability report. Companies choose to disclose negative indicators in their sustainability reports. This is certainly related to the positive image the company wants to build in front of its stakeholders. Companies tend to disclose negative information that doesn't have negative impacts on their image. For example, companies continue to disclose the number of work accidents that have occurred in their companies but they do not disclose the deliberate burning of forests or the deliberate disposal of waste into rivers or tax evasion. Companies also tend not to disclose negative information completely. For example, companies only write about actions that are not in accordance with the law by them but they did not explain what kind of action it means. This causes sustainability reports look to be a kind of too good to be true, because most of the information contained is positive information. The limitation of this research is that this study only uses SR as a basis for assessing fraud by companies. For future studies, the research should also use detailed interviews with companies to better analyze in detail why companies disclose or not disclose information in their sustainability reports.

\section{References}

[1] T. J. Brown and P. A. Dacin, "The company and the product: Corporate associations and consumer product responses," J. Mark., 1997, doi: 10.2307/1252190.

[2] C. Xie and R. P. Bagozzi, "Consumer responses to corporate social irresponsibility: The role of 
moral emotions, evaluations, and social cognitions," Psychol. Mark., 2019, doi: 10.1002/mar.21197.

[3] J. Peloza and J. Shang, "How can corporate social responsibility activities create value for stakeholders? A systematic review," Journal of the Academy of Marketing Science. 2011, doi: 10.1007/s11747-010-0213-6.

[4] P. Antonetti and S. Maklan, "Social Identification and Corporate Irresponsibility: A Model of Stakeholder Punitive Intentions," Br. J. Manag., 2016, doi: 10.1111/1467-8551.12168.

[5] S. Romani, S. Grappi, and R. P. Bagozzi, "My anger is your gain, my contempt your loss: Explaining consumer responses to corporate wrongdoing," Psychol. Mark., 2013, doi: 10.1002/mar.20664.

[6] T. I. Vaaland, M. Heide, and K. Grønhaug, "Corporate social responsibility: Investigating theory and research in the marketing context," Eur. J. Mark., 2008, doi: $10.1108 / 03090560810891082$.

[7] M. Corciolani, F. Nieri, and A. Tuan, "Does involvement in corporate social irresponsibility affect the linguistic features of corporate social responsibility reports?," Corp. Soc. Responsib. Environ. Manag., 2020, doi: 10.1002/csr.1832.

[8] G. Heal, "Corporate social responsibility: An economic and financial framework," 2005, doi: 10.1057/palgrave.gpp.2510037.

[9] M. Kotchen and J. J. Moon, "Corporate social responsibility for irresponsibility," B.E. J. Econ. Anal. Policy, 2012, doi: 10.1515/1935-1682.3308.

[10] M. Riera and M. Iborra, "Corporate social irresponsibility: review and conceptual boundaries," Eur. J. Manag. Bus. Econ., 2017, doi: 10.1108/EJMBE-07-2017-009.

[11] U. Alniacik, E. Alniacik, and N. Genc, "How corporate social responsibility information influences stakeholders' intentions," Corp. Soc. Responsib. Environ. Manag., 2011, doi: $10.1002 / \mathrm{csr} .245$.

[12] R. Hooghiemstra, "Corporate communication and impression management - New perspectives why companies engage in corporate social reporting," J. Bus. Ethics, 2000, doi: 10.1007/97894-011-4311-0_7.

[13] I. Seele, P. \& Lock, "Instrumental and/or deliberative ? A typology of CSR communication tools," J. Bus. Ethics, vol. 13, pp. 401-414, 2015, [Online]. Available: http://doi.org/10.1007/s10551-014-2282-9.

[14] D. Tschopp and R. J. Huefner, "Comparing the Evolution of CSR Reporting to that of Financial Reporting,” J. Bus. Ethics, 2015, doi: 10.1007/s10551-014-2054-6.

[15] M. Morsing, "CSR Communication: What Is It? Why Is It Important?," in Corporate social responsibility: Strategy, communication, governance, A. Rasche, M. Morsing, and J. Moon, Eds. Cambridge: Cambridge University Press, 2017, pp. 281-306.

[16] P. Bansal and G. Kistruck, "Seeing is (not) believing: Managing the impressions of the firm's commitment to the natural environment," J. Bus. Ethics, 2006, doi: 10.1007/s10551-006-90219 .

[17] D. S. Dhaliwal, O. Z. Li, A. Tsang, and Y. G. Yang, "Voluntary nonfinancial disclosure and the cost of equity capital: The initiation of corporate social responsibility reporting," Account. Rev., 2011, doi: 10.2308/accr.00000005.

[18] R. Nikolaeva and M. Bicho, "The role of institutional and reputational factors in the voluntary adoption of corporate social responsibility reporting standards," J. Acad. Mark. Sci., 2011, doi: 10.1007/s11747-010-0214-5.

[19] A. K. Carroll, A. Buchholtz, Business and Society: Ethics and Stakeholder Management, Fifth. Mason (Ohio): South-Western Thomson Learning, 2003.

[20] J. G. Frynas and C. Yamahaki, "Corporate social responsibility: Review and roadmap of theoretical perspectives," Bus. Ethics, 2016, doi: 10.1111/beer.12115.

[21] A. Dahlsrud, "How corporate social responsibility is defined: An analysis of 37 definitions," Corp. Soc. Responsib. Environ. Manag., 2008, doi: 10.1002/csr.132.

[22] L. A. Mohr, D. J. Webb, and K. E. Harris, "Do consumers expect companies to be socially responsible? The impact of corporate social responsibility on buying behavior," J. Consum. Aff., 
2001, doi: 10.1111/j.1745-6606.2001.tb00102.x.

[23] K. Behringer and K. Szegedi, "The Role Of CSR In Achieving Sustainable Development Theoretical Approach,” Eur. Sci. Journal, ESJ, 2016, doi: 10.19044/esj.2016.v12n22p10.

[24] K. Rangan, L. Chase, and S. Karim, "The truth about CSR," Harvard Business Review. 2015.

[25] U. Holtschneider, Adoption of corporate social responsibility by Japanese companies. München: Iudicium, 2015.

[26] A. Mulky, "Are CSR activities directed towards sustainable development goals? A study in India," Pap. Present. 5th Int. OFEL Conf. Governance, Manag. Entrep., 2017, [Online]. Available: https://search.proquest.com/docview/1945555843?.

[27] L. C. Roca and C. Searcy, "An analysis of indicators disclosed in corporate sustainability reports," J. Clean. Prod., 2012, doi: 10.1016/j.jclepro.2011.08.002.

[28] M. Mason, "What Is Sustainability and Why Is It Important?," EnvironmentalScience.org, 2015. https://www.environmentalscience.org/sustainability (accessed Aug. 14, 2020).

[29] EPA, "Learn About Sustainability," 2020. https://www.epa.gov/sustainability/learn-aboutsustainability (accessed Sep. 04, 2020).

[30] University of "What Alberta, is Sustainability?" https://www.mcgill.ca/sustainability/files/sustainability/what-is-sustainability.pdf (accessed Aug. 13, 2020).

[31] J. E. Moore, A. Mascarenhas, J. Bain, and S. E. Straus, "Developing a comprehensive definition of sustainability," Implement. Sci., 2017, doi: 10.1186/s13012-017-0637-1.

[32] G. Aras and G. Sarıglu, Kurumsal Raporlamada Yeni Dönem: Entegre Raporlama. Tüsiad Publishing, 2015.

[33] G. Davis and C. Searcy, "A review of Canadian corporate sustainable development reports," J. Glob. Responsib., 2010, doi: 10.1108/20412561011079425.

[34] Global Reporting Initiative, "Global Reporting Initiative," 2006.

[35] Global Reporting Initiatives, "G4 Sustianable Guidelines,” Jakarta, 2013.

[36] D. Diouf and O. Boiral, "The quality of sustainability reports and impression management: A stakeholder perspective," Accounting, Audit. Account. J., 2017, doi: 10.1108/AAAJ-04-20152044.

[37] W. S. Albrecht, C. O. Albrecht, C. C. Albrecht, and M. F. Zimbelman, Fraud Examination. Boston: Cengage Learning, 2014.

[38] M. Steinmeier, "Fraud in Sustainability Departments? An Exploratory Study," J. Bus. Ethics, 2016, doi: 10.1007/s10551-015-2615-3.

[39] KPMG Accountants N. V., "The rising challenge of sustainability fraud," KPMG Netherlands Website, 2020. https://home.kpmg/nl/nl/home/insights/2020/06/the-rising-challenge-ofsustainability-fraud.html (accessed Aug. 14, 2020).

[40] G. M. Trompeter, T. D. Carpenter, N. Desai, K. L. Jones, and R. A. Riley, "A synthesis of fraud-related research," Auditing, 2013, doi: 10.2308/ajpt-50360.

[41] J. R. Kurpierz and K. Smith, "The greenwashing triangle: adapting tools from fraud to improve CSR reporting," Sustain. Accounting, Manag. Policy J., 2020, doi: 10.1108/SAMPJ-10-20180272 .

[42] H. H. Cristel Antonia Russel, Dale W. Russell, "Corporate Social Responsibility Failures: How do Consumers Respond to Corpo...: EBSCOhost," Springer Science+Business Media Dordrecht $2015,2015$.

[43] H. L. Zou, R. C. Zeng, S. X. Zeng, and J. J. Shi, "How Do Environmental Violation Events Harm Corporate Reputation?,” Bus. Strateg. Environ., 2015, doi: 10.1002/bse.1849.

[44] D. Philippe and R. Durand, "The impact of norm-conforming behaviors on firm reputation," Strateg. Manag. J., 2011, doi: 10.1002/smj.919.

[45] A. R. Reuber and E. Fischer, "Organizations behaving badly: When are discreditable actions likely to damage organizational reputation?," J. Bus. Ethics, 2010, doi: 10.1007/s10551-0090180-3.

[46] Z. Wang, T. S. Hsieh, and J. Sarkis, "CSR Performance and the Readability of CSR Reports: Too Good to be True?," Corp. Soc. Responsib. Environ. Manag., 2018, doi: 10.1002/csr.1440. 